\title{
AKTIVITAS BAURAN PROMOSI UNIT USAHA SYARIAH PT BANK PERMATA TBK (Studi Deskriptif Kualitatif Eksekusi Co-Branding dan Sponsorship Permata Bank Syariah dengan Persib 2017-2018)
}

\author{
Riki Arswendi, Dewi Sad Tanti, Andi Herlina \\ Fakultas Ilmu Komunikasi \\ Universitas Mercu Buana Jakarta \\ Jl. Meruya Selatan No. 1, Jakarta Barat \\ riki.arswendi@mercubuana.ac.id; dstanti@gmail.com
}

\begin{abstract}
Marketing competition in the banking industry is increasingly ultracompetitive, triggering the Sharia Business Unit of PT Bank Permata Tbk (PermataBank Syariah) to carry out promotions in a way that has never been done before, namely to carry out sports sponsorship initiatives for PERSIB club football. This research was conducted to determine the promotional mix activities of Permata Bank Syariah in conducting co-branding $\mathcal{E}$ sponsorship which is expected to increase Bobotoh's awareness on the Permata Syariah brand. This study uses Marketing Communication Theory from Philip Kotler and uses the Balance Sheet Theory from Fritz Heider with a qualitative approach with a qualitative descriptive format. The results of the study discussed the execution of co-branding $\mathcal{E}$ sponsorship carried out by Permata Bank Syariah, from the planning, implementation to program evaluation stages. Co-branding activities in the promotional mix implemented by PermataBank Syariah and PERSIB are quite effective in gaining Bobotoh awareness and generating new account acquisitions. Whereas sponsorship activities carried out by PermataBank Syariah proved to support PermataBank Syariah obtaining marketing publicity and can access the commercial potential of PERSIB to be exploited and optimized.
\end{abstract}

Keywords: Permata Bank Syariah, co-branding, awareness. 


\begin{abstract}
Abstrak
Persaingan pemasaran di industry perbankan yang semakin ultra kompetitif, menjadi trigger bagi Unit Usaha Syariah PT Bank PermataTbk (PermataBank Syariah) untuk melakukan promosi dengan cara yang belum pernah dilakukan sebelumnya yaitu melakukan inisiatif sport sponsorship kepada klub sepakbola PERSIB. Penelitian ini dilakukan untuk mengetahuia ktivitas bauran promosi PermataBank Syariah dalam melakukan co-branding \& sponsorship yang diharapkanakan meningkatkan awareness Bobotoh pada brand Permata Syariah. Penelitian ini menggunakanTeori Komunikasi Pemasaran dari Philip Kotler dan menggunakan Teori Keseimbangan dari Fritz Heider dengan pendekatan kualitatif dengan format deskriptif kualitatif. Hasil penelitian membahas eksekusi co-branding \& sponsorship yang dijalankan oleh Permata Bank Syariah, mulai tahap perencanaan, implementasi hingga evaluasi program. Aktivitas cobranding dalam bauran promosi yang diimplementasikan oleh Permata Bank Syariah dan PERSIB cukup efektif mendapatkan awareness Bobotoh dan menghasilkan akuisisi rekening baru. Sedangkan aktivitas sponsorship yang dilakukan olehPermata Bank Syariah terbukti mendukung Permata Bank Syariah memperoleh marketing publicity dan dapat mengaksespotensi komersial PERSIB untuk dieksploitasi dan dioptimalkan.
\end{abstract}

Katakunci: Permata Bank Syariah, co-branding, awareness.

\section{A. PENDAHULUAN}

Di tengah persaingan pasar yang semakin hari semakin ultrakompetitif, semakin banyak perusahaan yang menawarkan produk atau jasa yang sejenis, sehingga sebuah perusahaan akan berusaha keras untuk menyusun strategy marketing dan implementasinya termasuk aktivitas promosi untuk memperkenalkan perusahaannya, produk maupun jasa, tergantung dari tujuan promosi itu sendiri. Hal ini terjadi hampir disemua industri jasa maupun produsen produk, tidak terkecuali pada industri perbankan. Jika sebuah perusahaan bisa memiliki sebuah citra yang baik dan dikenal oleh khalayak (awareness yang baik), maka produk atau jasa yang ditawarkan berpotensi tinggi untuk diterima dan laku di pasaran sehingga diharapkan dapat memenuhi tujuan promosi yang utamanya bermuara untuk tercapainya target ekonomi perusahaan.

$\begin{array}{cccr}\text { Pada } & \text { kesempatan } & \text { ini, } & \text { Peneliti } \\ \text { melakukan } & \text { penelitian } & \text { pada } & \text { sektor }\end{array}$

perbankan. Tentang bagaimana sektor perbankan sebagai industri jasa dengan fungsi menggalang dana masyarakat sekaligus sebagai lembaga yang menyalurkan dana dengan berbagai dinamika melalui komunikasi dan promosi. Sektor perbankan dituntut untuk semakin kreatif terlebih lagi promosi yang dilakukan pada Unit Usaha Syariah pada suatu Bank Swasta Nasional yang belum berstatus Bank Umum Syariah.

Tantangan umum pada industri perbankan adalah bagaimana upaya penyaluran kredit dan pembiayaan yang semakin selektif serta upaya perolehan penghimpunan dana yang kian kompetitif. Kabar baiknya, potensi pertumbuhan Perbankan Syariah masih sangat besar dengan menunjukkan pertumbuhan yang lebih tinggi dibandingkan dengan pertumbuhan total perbankan nasional yang tumbuh $10 \%$ di 2017. Pertumbuhan asset perbankan syariah yang tinggi ini juga mendorong peningkatan pangsa pasar 
perbankan syariah terhadap total industri perbankan nasional, dari 5,03\% diakhir 2016 menjadi 5,74\% dibulan Desember 2017 (laporan tahunan Bank Permata tahun $2017 ; 189)$.

Memperhatikan Indonesia adalah negara dengan penduduk Muslim terbesar di dunia, maka potensi perumbuhan perbankan syariah cukup besar. Namun dari sisi kelengkapan dan variasi produk perbankan syariah saat ini masih tertinggal dibandingkan dengan produk perbankan konvensional, sehingga peluncuran produk-produk baru perbankan syariah yang disertai dengan edukasi dan promosi kepada masyarakat yang semakin masif, diyakini mampu turut mendorong laju pertumbuhan perbankan syariah.

PT Bank Permata Tbk, salah satu bank terkemuka di Indonesia juga turut menangkap peluang untuk mengembangkan pelayanan perbankan berbasis syariah sesuai dengan perkembangan kebutuhan masyarakat Indonesia. Sehingga pada tanggal 10 November 2004, resmi membentuk Unit Usaha Syariah yang masih bernaung di bawah entitas PT Bank Permata Tbk, yang lebih dikenal sebutan Permat Bank Syariah. Perkembangan total pendanaan Permata Bank Syariah saat ini meningkat sebesar Rp. 1,34 trilyun selama tahun 2017 menjadi Rp. 14,25 trilyun dan berkontribusi 13\% terhadap total pendanaan Permata Bank. Pertumbuhan pendanaan tersebut ditopang oleh peningkatan produktivitas dari jaringan distribusi Permata Bank Syariah yang terdiri dari 17 kantor cabang syariah, lebih dari 300 kantor layanan syariah dan juga 18 Layanan Satu Atap. PermataTabungan iB Haji merupakan salah satu produk unggulan PermataBank Syariah. Produk ini merupakan jawaban terhadapkebutuhanibadah haji masyarakat. Permata Bank Syariah sangat mendukung program pemerintah khususnya yang dilakukan Kementerian Agama dalam Pelayanan Pendaftaran Haji Satu Atap. 'Layanan Satu Atap' adalah counter bank syariah/unit usaha syariah yang berada di dalam lingkungan kantor Kementerian Agama dalam memberikan pelayanan pendaftaran haji satu atap. Dengan layanan ini calon jamaah haji dapat melakukan pembukaan dan penyetoran dana haji-nya secara langsung disatu tempat, sehingga tujuan one stop haji service dapat tercapai. Permata Bank Syariah merupakan bank syariah pertama yang memberi layanan satu atap pendaftaran haji secara online di kantor-kantor Kementerian Agama di daerah. (laporan tahunan Bank Permata tahun 2017;189).

Pada aspek pemasaran, strategi pemasaran produk-produk jasa perbankan Permata Bank pada dasarnya mengedepankan dua pendekatan, yaitu:

1. Pembinaan hubungan jangka panjang yang berkualitas dengan Nasabah.

2. Optimalisasi sinergi, dengan menyediakan produk dan layanan yang menyeluruh untuk melayani berbagai kebutuhan Nasabah.

Terkait dengan startegi pemasaran produk di atas, maka pada bulan April 2017 hingga Maret 2018, diluncurkan dan diimplementasikannya program aktivasi berupa co-branding dan sponsorship PermataBank Syariah bersama dan kepada PERSIB, sebuah klub sepakbola yang berasal dari Kota Bandung. 


\section{B. METODE PENELITIAN}

Penelitian ini peneliti menggunakan tipe penelitian deskriptif kualitatif. Penelitian deskriptif lebih mengemukakan gambaran dan pemahaman (understanding) mengenai bagaimana dan mengapa suatu gejala atau realitas komunikasi terjadi. Tipe penelitian ini digunakan untuk menjelaskan atau mendespkripsikan mengenai apa yang diteliti tanpa adanya manipulasi data, dengan melakukan observasi dan wawancara untuk mendapatkan data yang diperlukan dalam penelitian. penelitian ini juga menyajikan penjelasan mengenai objek yang diteliti dengan sebenar-benarnya sesuai dengan apa yang terdapat di lapangan.

Sedangkan penelitian kualitatif menurut Moleong (2007:6) adalah penelitian yang bermaksud untuk memahami fenomena tentang apa yang dialami oleh subjek penelitian misalnya perilaku, persepsi, motivasi, tindakan, dll., secara holistik, dan dengan cara deskripsi dalam bentuk kata-kata dan bahasa, pada suatu konteks khusus yang alamiah dan dengan memanfaatkan berbagai metode alamiah. tata cara yang berlaku dalam masyarakat serta situasi-situasi tertentu, termasuk tentang hubungan, kegiatan-kegiatan, sikap -sikap, dan pandangan-pandangan, serta, proses-proses yang sedang berlangsung dan pengaruh-pengaruh dari suatu fenomena

\section{HASIL DAN PEMBAHASAN}

Guna mengetahui aktivitas bauran promosi Unit Usaha Syariah PT Bank Permata Tbk dalam melakukan co-branding dan sponsorship yang dieksekusi oleh PermataBank Syariah periode April 2017 sampai dengan Maret2018, yang diharapkan

104 | Jurnal An-Nida, Vol. 11, No. 2, Juli-Desember 2019 dapat meningkatkan awareness supporter PERSIB yang dijuluki "Bobotoh" terhadap brand PermataSyariah dan akan melakukan action untuk memanfaatkan produk dan layanan perbankan PermataBank Syariah.

Peneliti melakukan pendekatan kualitatif dengan cara melakukan wawancara mendalam kepada para narasumber (Marketing specialist PermataBank Syariah, Head of Liabilities Permatan Bank Syariah dan Head of Mmedia Flatfom dan Vice President sales and Marketing Persib

\section{Tujuan dan Alasan Program}

Sponsorship \& co-Branding

Hasil penelitian terkait tujuan utama dilakukannnya program sponsorship ini adalah untuk menciptakan awareness Bobotoh terhadap brand Permata Syariah dengan demikian diharapkan Bobotoh pada akhirnya akan melakukan pembukaan rekening produk tabungan PermataBank Syariah. Hasil wawancara kepada ketiga narasumber dari Permata Bank terkait tujuan utama program sponsorship ini adalah sebagai berikut:

"Tujuan sponsorship ini selain untuk meningkatkan awereness dari PermataBank Syariah sebagai Bank Syariah di Indonesia" (jawaban Bapak Widi Aprianto)

"Tujuan program sponsorship ini untuk meningkatkan awareness terhadap brand Permata Bank dan PermataBank Syariah, menarik perhatian publik atas solusi perbankan syariah yang ditawarkan PermataBank Syariah, meningkatkan jumlah akuisisi melalui sentiment-driven program, long-term financial benefits melalui penempatan dana nasabah" (jawaban Ibu Olivia)

ISSN : 2085-3521, E-ISSN : 2548-9054 
"Sponsorship yang disertai dengan cobranding (terutama Kartu Debit co-branding dan Kartu Membership PERSIB) dipilih agar dapat memaksimalkan beneift yang diberikan kepada para fans PERSIB. Tidak hanya terfokus pada branding, dengan adanya Kartu Debit co-branding, para fans PERSIB dapat menikmati beberapa benefit produkPermataBank Syariah dengan tetap mengedepankan identitasnya sebagai Bobotoh" (jawaban Ibu Olivia).

"Kerjasama dengan PERSIB didasarkan pada beberapa pertimbangan bisnis antara lain:

Strategi inklusi dan literasi keuangan Syariah.

Memperbesar penertrasi produk perbankan syariah yang ditawarkan oleh Permata Bank.

Memadukan daya tarik PERSIB dan Permata Bank / PermataBank Syariah sebagai suatu kekuatan baru dalam menjaring jumlah nasabah dan penggemar" (jawaban Bapak Bima Raditya)

"Sponsorship dan co-branding menjadi pliihan karena di dalamnya sudah mencakup berbagai aktivitas dan media pemasaran serta akuisisi" (jawaban Bima Raditya)

\section{Alasan bersponsorship dengan PERSIB}

Adanya rasa tanggung jawab moral untuk mendukung kemajuan olahraga di Indonesia khususnya olahraga sepakbola, memberikan kemudahan kepada masyarakat yang berniat menunaikan ibadah Haji (porsi haji tertinggi saat ini terkonsentrasi di Jawa Barat yang merupakan 'wilayah' Bobotoh), memberi solusi pilihan berbank syariah yang modern. PermataBank Syariah melihat adanya peluang mempromosikan dan memasarkan produk -produk tabungan unggulan
PermataBank Syariah, jika 'masuk' ke Bobotoh melalui program sponsorship ke PERSIB (penggunaan sentiment-driven program). Faktor-faktor tersebut adalah hal utama yang mendasari keputusan bermitra/memberikan sponsor ke PERSIB.

Berikut kutipan hasil wawancara dengan 3 Narasumber dari Permata Bank "terkait hal-hal yang menjadi pertimbangan dilakukannya program sponsorship kepada klub sepakbola PERSIB Bandung:

"Tujuan sponsorship ini selain untuk meningkatkan awereness dari PermataBank Syariah sebagai Bank Syariah di Indonesia, PermataBank Syariah melihat bahwa PERSIB sebagai tim sepakbola kebanggaan daerah Jawa Barat menjadi daya tarik yang potensial untuk menawarkan produk produk tabungan PermataBank Syariah seperti Tabungan Haji dan Tabungan iB Bebas. Dari hasil riset Kementerian Agama di tahun 2016, 19 \% kuota Haji Nasional diambil dari daerah Jawa Barat, hal ini yang menjadi dasar PermataBank Syariah melakukan kerjasama (sponsorship) dengan PT Persib Bandung Bermartabat" (jawaban Bapak Widi Aprianto)

"Hal yang menjadi pertimbangannya, yaitu: PERSIB merupakan salah satu klub sepakbola nasional yang memiliki penggemar cukup loyal dengan potensi jumlah fans PERSIB atau dikenal dengan Bobotoh PERSIB yaitu sebanyak 9 juta follower di facebook dan sekitar 2 juta follower di instagram. PERSIB di bawah manajemen PT. Persib Bandung Bermartabat juga merupakan klub sepakbola yang dikelola dengan manajemen yang profesional. Wilayah Jawa Barat yang merupakan propinsi dengan kuota haji nasional tertinggi yaitu sebesar 19\% dari kuota seluruh Indonesia, sehingga dapat bersinergi dengan produk Tabungan Haji 
yang dimiliki oleh PermataBank Syariah.

Selain produk Tabungan Haji, PermataBank

Syariah juga memiliki produk lain yang sesuai dengan kebutuhan para Bobotoh diantaranya PermataTabungan iB Bebas dan PermataTabungan iB Payroll" (jawaban Ibu Olivia) .

"Sebenarnya bukan olahraga secara umum, tapi lebih karena nilai universal dari "sepakbola' itu sendiri. Karena sepakbola sebagai salah satu olahraga paling demokratis (melibatkan banyak pemain), peraturan yang mudah dimengerti, bisa dimainkan berbagai kelompok umur, dan peralatan pelengkap permainan yang relatif tidak mahal, ... ini semua yang menjadikan sepakbola sebagai salah satu kegiatan komunal yang merumput (locally rooted) dan merakyat (globally recognized). Pertimbangan ini yang menjadi pintu masuk dalam mendukung inisiatif inklusi dan literasi keuangan ... keuangan syariah pada khususnya" (jawaban Bapak Bima Raditya)

Selain itu Peneliti juga menemukan bahwajika menurut perspektifPermataBank Syariah, asset terutama PERSIB ada jumlah Bobotoh yang besar + / - 14 juta fans, namun hal ini berbeda dalam perspektif PERSIB. Bagi PERSIB tiga komponen utama asset PERSIB adalah team, logo dan nama besar PERSIB itu sendiri. Hal ini diungkapkan oleh Narasumber PERSIB, Bapak Girindra dalam hasil

"Tiga komponen utama asset PERSIB adalah; team, logo dan nama PERSIB itu sendiri. Jadi ngga bisa sembarangan bisa make asset PERSIB kecuali sponsornya.

\section{Target market dan Target Demografis}

Berdasarkan data hasil wawancara, target market dari program aktivasi ini adalah para Bobotoh. Adapun target demografisnya membidik wilayah propinsi Jawa Barat. Berikut kutipan hasil wawancara dengan para Narasumber dari Permata Bank terkait pertanyaan Peneliti mengenai siapakahtarget marketdalam program sponsorship ini? Berikut kutipan jawaban wawancaranya:

"Target marketnya ya para fans PERSIB dan warga Jawa Barat ... Bobotoh lah" (jawaban Bapak Widi Aprianto)

"PermataBank Syariah melihat bahwa PERSIB sebagai tim sepakbola kebanggaan daerah Jawa Barat menjadi daya tarik yang potensial untuk menawarkan produk produk tabungan PermataBank Syariah seperti Tabungan Haji dan Tabungan iB Bebas. Dari hasil riset Kementerian Agama di tahun 2016, 19 \% kuota Haji Nasional diambil dari daerah Jawa Barat, hal ini yang menjadi dasar PermataBank Syariah melakukan kerjasama (sponsorship) dengan PT Persib Bandung Bermartaban (jawaban Bapak Widi Aprianto)

"Target market dalam program ini khususnya adalah para fans PERSIB (Bobotoh). Namun demikian, dengan ditampilkannnya logo PermataBank Syariah pada jersey resmi PERSIB dan beberapa atribut marketing lainnya, brand PermataBank dan PermataBank Syariah mendapatkan exposure yang jauh lebih luas lagi ke seluruh Indonesia baik melalui media cetak maupun media elektronik" (jawaban Ibu Olivia)

"Wilayah Jawa Barat yang merupakan propinsi dengan kuota haji nasional tertinggi yaitu sebesar 19\% dari kuota seluruh Indonesia, sehingga dapat bersinergi dengan produk Tabungan Haji yang dimiliki oleh PermataBank Syariah" (jawaban Ibu Olivia) "Padaawalnyakamimembidik Bobotoh secara keseluruhan, akan tetapi setelah berjalan 
pada periode pertama kami mendapati bahwa masyarakat yang tertarik dengan produk dan solusi perbankan yang ditawarkan melaui sinergi ini ternyata adalah irisan dari target market existing Permata Bank dan PermataBank Syariah yang juga adalah penggemar PERSIB atau sepakbola pada umumnya" (jawaban Bapak Bima Raditya) "Jangkauan operasional cabang Permata Bank dalam mendampingi kegiatan operasional PERSIB yang mayoritas berjalan di wilayah Jawa Barat dan juga daerah-daerah lain di Indonesia" (jawaban Bapak Bima Raditya)

\section{Positioning}

Berdasarkan hasil penelitian, Peneliti memaknai positioning yang ingindibentuk oleh PermataBank Syariah dikhalayak Bobotoh melalui program sponsorship ini adalah; PermataBank Syariah adalah banknya PERSIB kebanggaan Bobotoh, sehingga banknya PERSIB = banknya Bobotoh juga, bank yang senantiasa berada di tengah-tengah masyarakat (Bobotoh) yang memberikan solusi financialberkonsep syariah dengan teknologi $\mathrm{m}$ o d e $\mathrm{r} n$. Singkatnya adalah 'PermataSyariah banknya Bobotoh'.

Hal ini merujuk pada kutipan hasil wawancara dengan 3 orang narasumber dari Permata Bank sebagai berikut:

"Positioning yang ingin dibentuk kirakira gini .... PERSIB kebanggaan saya aja banknya pilih PermataBank Syariah, saya juga ikut PERSIB ...PermataBank Syariah, bank saja juga" ( jawaban Bapak Widi Aprianto)

"Sebagai bank yang senantiasa berada di tengah-tengah masyarakat untuk memberikan solusi financial dengan konsep syariah dan didukung dengan teknologi yang modern" (jawaban Ibu Olivia)

"Positioningnya ingin mewujudkan brand promise "untuk hidup yang lebih bernilai" ...seperti apa? Silakan diterjemahkan sendiri, semudah barangkali, bagi seorang nasabah yang juga Bobotoh, lebih baik berbank dengan bank nya PERSIB... daripada ke Bank lainnya..." (jawaban Bapak Bima Raditya)

\section{KESIMPULAN}

PermataBankSyariahmendapatkansa mbutan yang baikdariparaBobotoh, salah satunya adalah dikarenakan Permata Bank Syariah memberikan benefit produk yang dapatdinikmati olehpara Bobotoh secara berkelanjutan.

1. Permata Bank dan Permata BankSyariah juga mendapatkan exposure branding yang sangat bagus baik sepanjang musim tanding maupun diluar musim tanding.

2. Permata Bank Syariah berhasil melakukan akuisisi terhadap kurang lebih 10.200 akun baru terkait dengan sponsorship ini pada periode pertama, cukup berkontribusi meningkatkan jumlah nasabah Permata Bank Syariah yang per-Juni 2018 tercatat +/- 708 ribunasabah"

\section{E. IMPLIKASI DAN KETERBATASAN PENELITIAN}

Penelitian ini dilakukan untuk memberikan gambaran stategi promosi yang dilakukan oleh PermataBank Syariah pada tahun 2017-2018 dengan pendekatan kualitatif. 
Pendekatan kuantitatif diharapkan bisamenjadi alternatif yang bisa dilakukan oleh peneliti selanjutnya agar mendapatkan jasil ayng lebih komprehensif.

Selain itu, saat ini sudah berada di tahun 2019. Maka jenjang atau jangka waktu riset mungkin bisa perbaharui dari 20172019 untuk mengukur efektivitas promosi yang dilakukan oleh Bank Permata Syariah.

\section{DAFTAR PUSTAKA}

Sumber Buku:

Kotler Philip, Kartajaya Hermawan dan Setiawan Iwan. (2010). Mulai dari Produk ke Pelanggan ke Human Spirit Marketing 3.0 .Jakarta: Erlangga.

Kriyantono, Rachmat. (2008). Teknik Praktis Riset Komunikasi. Jakarta: Kencana Prenada Media Group, Cetakan ketiga.

Laksana, Fajar. (2008). Manajemen Pemasaran; Pendekatan Praktis. Yogyakarta: Graha Ilmu.

Moleong, Lexy J. (2007). Metodologi Penelitian Kualitatif. Bandung :Remaja Rosdakarya.

Morissan. (2014). Periklanan Komunikasi Pemasaran Terpadu. Jakarta:Kencana Prenadana.

Tiptono, Fandy. (2008). Service Management. Yogyakarta: Andi Offset.

Sumber Jurnal

Atmodjo, Juwono Tri. (2015) “Corporate Identity dan Personality Bank Syariah di Surat Kabar Nasional (Tekstual Analisis Konstruksi Melalui Publikasi Perusahaan)". Jurnal Visi Komunikasi/Vol.14, No.01, Mei 2015: 46-50

Dewi Nur Permatasari. (2014) Analisis Pengaruh Kualitas Produk dan Bauran Promosi Terhadap Loyalitas Konsumen Smartphone Blackberry". Jurnal MIX, Vol IV No.1: 57-69.

Akcay,Selcuk.(2011). Causality Relationship Between Total R\&D Investment and Economic Growth: Evidence From United States. The Journal of Faculty of Economics and Administrative Sciences, 
16(1), 79-92.

Lim Yosep. (2013). Pengaruh Harga dan Promosi Terhadap Keputusan Konsumen Dalam Pembelian Cat Merek Mowilex di Jakarta". Jurnal MIX, Vol III,: 373-38.

\section{Sumber Lain:}

Laporan tahunan PERSIB. (2017). Laporan Tahunan. Bandung.

Laporan tahunan. (2017). Bank permata syariah. Bandung. 